\title{
Pengaruh Kombinasi Arus Tabung Sinar-X dan Waktu Eksposi Terhadap Contrast to Noise Ratio (CNR) dengan menggunakan Computed Radiography
}

\author{
Effect of Combination of X-Ray Tube Current and Exposure \\ Time on Contrast to Noise Ratio (CNR) using Computed \\ Radiography
}

\author{
Ni Wayan Mega Savira Utami ${ }^{*}$, Ni Nyoman Ratini ${ }^{2}$ I Putu Eka Juliantara ${ }^{3}$ \\ ${ }^{1,2}$ Program Studi Fisika, Fakultas Matematika dan Ilmu Pengetahuan Alam, Universitas Udayana, \\ Kampus Bukit Jimbaran, Badung, Bali, Indonesia 80361 \\ ${ }^{3}$ Akademi Teknik Radiodiagnostik dan Radioterapi (ATRO) Bali, Jalan Tukang Batanghari VII No. 21, \\ Dauh Puri Klod, Denpasar Barat, Denpasar, Bali, Indonesia, 80234 \\ Email: megasavirautami@student.unud.ac.id*,nymratini@unud.ac.id, ekaj.atro@gmail.com
}

\begin{abstract}
Abstrak - Telah dilakukan penelitian untuk mengetahui pengaruh kombinasi arus tabung sinar-X dan waktu eksposi terhadap Contrast to Noise Ratio (CNR) dengan menggunakan Computed Radiography (CR). Penelitian bertujuan untuk mengetahui kombinasi arus tabung sinar-X dan waktu eksposi terhadap kualitas citra sinar-X dengan menggunakan $C R$ dan nilai optimal CNR-nya. Alat bantu yang digunakan berupa step wedge dengan penambahan ketebalan 1,5 mm pada setiap step, tegangan tabung konstan sebesar $56 \mathrm{kV}$, arus tabung sinar-X dan waktu eksposi sebesar 5 mAs. Variasi nilai 5 mAs ke dalam arus tabung sinar-X dan waktu eksposi sebagai berikut: variasi 1 sebesar $100 \mathrm{~mA}$ dan 0,050 s, variasi 2 sebesar $125 \mathrm{~mA}$ dan 0,040 s, variasi 3 sebesar $160 \mathrm{~mA}$ dan 0,032 s, variasi 4 sebesar $200 \mathrm{~mA}$ dan 0,025 s, dan variasi 5 sebesar $250 \mathrm{~mA}$ dan 0,020 s. Pembacaan nilai $I_{s}, I_{b}$, dan $\sigma_{b}$ menggunakan software program RadiAnt DICOM VIEWER 2020.1 (64 bit) dan analisis pengaruh kombinasi arus tabung sinar-X dan waktu eksposi terhadap nilai CNR menggunakan IBM SPSS Statistic 26 dengan Uji One Way-ANOVA. Hasil analisis menunjukkan bahwa kombinasi arus tabung sinar-X dan waktu eksposi tidak berpengaruh terhadap nilai CNR. Nilai optimal CNR adalah 42,37 diperoleh pada variasi 3 yaitu besar arus tabung sinar-X adalah $160 \mathrm{~mA}$ dan waktu eksposi sebesar 0,032 s.
\end{abstract}

Kata kunci: Arus tabung, waktu eksposi, Contrast to Noise Ratio, step wedge, Computed Radiography

\begin{abstract}
A research has been carried out to determine the effect of the combination of $X$-ray tube current and exposure time on the Contrast to Noise Ratio (CNR) using Computed Radiography (CR). This study aims to determine the combination of X-ray tube current and exposure time on the quality of $X$-ray images using $C R$ and the optimal value of its CNR. The tool used is a step wedge with an additional $1.5 \mathrm{~mm}$ thickness at each step, a constant tube voltage of $56 \mathrm{kV}$, an X-ray tube current and an exposure time of $5 \mathrm{mAs}$. Variations in the value of $5 \mathrm{mAs}$ into the $X$-ray tube current and exposure time are as follows, variation 1 of $100 \mathrm{~mA}$ and $0.050 \mathrm{~s}$, variation 2 of $125 \mathrm{~mA}$ and $0.040 \mathrm{~s}$, variation 3 of 160 $\mathrm{mA}$ and $0.032 \mathrm{~s}$, variation 4 of $200 \mathrm{~mA}$ and $0.025 \mathrm{~s}$, and variation 5 of $250 \mathrm{~mA}$ and $0.020 \mathrm{~s}$. Reading the values of $I_{s}, I_{b}$, and $\sigma_{b}$ using the RadiAnt DICOM VIEWER 2020.1 software program (64 bit) and analyzing the effect of the combination of $X$-ray tube current and exposure time on CNR values using IBM SPSS Statistic 26 with One Way-ANOVA Test. The results of the analysis showed that the combination of $X$-ray tube current and exposure time had no effect on the CNR value. The optimal value of CNR is 42.37, obtained in variation 3, namely the $X$-ray tube current is $160 \mathrm{~mA}$ and the exposure time is $0.032 \mathrm{~s}$.
\end{abstract}

Key words: Tube current, exposition time, Contrast to Noise Ratio, step wedge, Computed Radiography

\section{Pendahuluan}

Saat ini penggunaan citra digital telah banyak dilakukan. Citra digital adalah citra yang dihasilkan dari pengolahan dengan menggunakan komputer. Citra yang dihasilkan oleh perangkat Computed Radiography (CR) termasuk kedalam tipe citra digital, dan dapat digunakan untuk mendiagnosa suatu penyakit, oleh karena itu semua perangkat CR harus berfungsi sesuai standar yang telah ditetapkan. 
Adanya digitalisasi citra pada CR menyebabkan kualitas citra dapat di ukur melalui nilai Contrast to Noise Ratio (CNR) [1].

Parameter CNR menggambarkan seberapa besar intensitas sinyal dapat dibedakan dengan latar. Citra yang menunjukkan nilai CNR yang tinggi akan mudah untuk didiagnosa, sedangkan citra yang mempunyai nilai CNR yang rendah akan sulit untuk didiagnosa karena sulit membedakan objek yang difoto dengan latar objek tersebut. Sehingga sangat penting untuk memperhatikan nilai CNR untuk menghasilkan citra dengan kualitas yang baik. Untuk menghasilkan nilai CNR yang optimal atau yang baik harus memperhatikan densitas dan kontras radiografi yang dihasilkan oleh karakteristik tabung sinar-X dan faktor eksposi [2].

Salah satu karakteristik tabung sinar-X yang digunakan yaitu kemiringan anoda yang dirancang untuk mengarahkan berkas sinar-X ke objek. Kemiringan anoda akan menyebabkan penyebaran intensitas sinar-X yang tidak merata dan berpengaruh pada kualitas radiograf yang dihasilkan meskipun objek mempunyai ketebalan yang sama, hal ini disebut dengan Anode Heel Effect [3]. Pada saat eksposi, objek dengan ketebalan yang paling tebal diletakkan pada arah katoda sedangkan objek dengan bagian yang paling tipis diletakkan pada arah anoda. Jumlah intensitas radiasi antara anoda dan katoda pada tabung sinar-X dipengaruhi oleh Anode Heel Effect sehingga secara otomatis efek ini juga akan berpengaruh terhadap densitas radiograf yang dihasilkan [4].

Selain kemiringan dari anoda, proses eksposi menggunakan sinar-X untuk menghasilkan citra digital harus memperhatikan faktor eksposi. Pengaturan faktor eksposi yang tepat dapat menghasilkan densitas dan kontras radiografi yang optimal yaitu akan dapat menunjukkan perbedaan derajat kehitaman yang jelas antar organ yang mempunyai kerapatan berbeda, sehingga menghasilkan kualitas citra yang memberikan nilai diagnosa yang baik. Faktor eksposi yang dimaksud adalah tegangan tabung sinar-X $(\mathrm{kV})$, arus tabung sinar-X dan waktu eksposi (mAs). Perkalian arus tabung sinar-X (mA) dan waktu eksposi (s) akan menentukan kuantitas radiasi yang dihasilkan. Memberlakukan arus tabung sinar-X dan waktu eksposi (mAs) konstan dan memvariasikan nilai arus tabung sinar-X dan waktu eksposi (mAs) kedalam arus (mA) dan waktu eksposi (s) jika hasilnya konstan sesuai dengan arus tabung sinar-X dan waktu eksposi (mAs) yang diberikan maka energi radiasi untuk mencapai objek adalah sama [5].

Berdasarkan latar belakang diatas, sehingga dilakukan penelitian ini untuk mengetahui pengaruh kombinasi arus tabung sinar-X dan waktu eksposi terhadap Contrast to Noise Ratio (CNR) dengan menggunakan Computed Radiography.

\section{Landasan Teori}

\subsection{Pesawat sinar-X}

Pesawat sinar- $X$ adalah suatu alat yang digunakan untuk melakukan diagnosa medis dengan menggunakan sinar-X. Sinar-X yang dipancarkan dari tabung inersia diarahkan ke bagian tubuh yang akan didiagnosis. Sinar-X akan menembus dan melewati bagian tubuh, kemudian ditangkap oleh film sehingga terbentuknya citra bagian tubuh yang di eksposi [6]. Pesawat sinar-X terdiri dari control panel, transformator, generator dan tabung sinar-X. Dalam pengoperasian pesawat sinar-X, control panel digunakan sebagai pengatur parameter. Sistem sinar-X standar memiliki tiga prinsip pengendalian, yaitu tegangan $(\mathrm{kV})$, arus tabung $(\mathrm{mA})$, dan waktu eksposi (s). Transformator adalah alat elektromagnetik yang dapat mengubah tegangan arus bolak-balik dan menaikkan atau menurunkan tegangan. Generator berfungsi bukan untuk menyediakan atau membangkitkan energi, tetapi untuk mengubah energi listrik menjadi bentuk produksi sinar-X [7].

Tabung sinar-X merupakan salah satu komponen dari pesawat sinar-X, dimana tabung sinar-X adalah ruang hampa udara yang terbuat dari kaca tahan panas, tempat dihasilkannya sinar-X. Untuk menghasilkan sinar- $X$ diperlukan tabung sinar-X hampa udara, di mana dalam tabung tersebut terdapat elektron-elektron yang diarahkan pada target dengan kecepatan tinggi. Melalui proses di atas, muncul keadaan di mana sebagian besar energi elektron diubah menjadi panas $(99 \%)$ dan sebagian kecil (1\%) diubah menjadi sinar-X [3].

\subsection{Anode Heel Effect}

Anoda adalah elektroda positif dari tabung sinar-X dan fungsinya untuk menerima tumbukan elektron dari filamen yang dipancarkan sinar-X. Daerah anoda yang ditembaki oleh elektron disebut dengan sasaran target. Kemiringan target akan mempengaruhi perubahan ukuran focal spot dan Anode Heel Effect. Anode Heel Effect adalah distribusi sinar-X yang tidak merata pada sumbu yang sejajar dengan 
sumbu tabung sinar-X. Anode Heel Effect akan mempengaruhi intensitas radiasi antara anoda dan katoda pada tabung sinar-X, sehingga efek ini secara otomatis akan berpengaruh terhadap densitas radiograf yang dihasilkan. Anode Heel Effect dapat dimanfaatkan dengan menempatkan objek dengan ketebalan yang berbeda-beda sesuai dengan posisi anoda dan katoda pada tabung sinar-X yaitu dengan menempatkan objek yang lebih tebal pada daerah katoda dan objek yang lebih tipis pada daerah anoda [3].

\subsection{Arus Tabung dan Waktu Eksposi (mAs)}

Peningkatan arus tabung sinar- $X$ akan menambah intensitas sinar- $X$ dan penurunan arus tabung sinar- $X$ akan mengurangi intensitas sinar- $X$, sehingga intensitas sinar- $X$ atau derajat terang gelap dapat diatur dengan mengubah arus tabung sinar-X. Waktu eksposi akan menentukan lamanya eksposi yang dilakukan. Kuantitas dari radiasi sinar-X dipengaruhi oleh kombinasi arus tabung sinar-X dan waktu eksposi. Kuantitas yang diterima oleh radiograf menyebabkan timbulnya rentang atau range densitas yang berbeda-berbeda pada radiografi [8].

Arus tabung sinar-X dan waktu eksposi merupakan faktor penting, terutama dalam hal mempengaruhi perubahan densitas film dengan semua variabel lainnya. Densitas adalah tingkat kehitaman atau kepadatan dari citra yang dihasilkan. Densitas berhubungan nilai $\mathrm{I}_{\mathrm{s}}$, dimana semakin kecil densitas maka nilai $I_{\mathrm{s}}$ akan semakin besar [9]. Semakin kecil nilai densitas maka semakin besar nilai kontras. Memberlakukan arus tabung sinar-X dan waktu eksposi (mAs) konstan serta memvariasikan nilai arus tabung sinar-X dan waktu eksposi (mAs) kedalam arus (mA) dan waktu eksposi (s), jika hasilnya konstan sesuai dengan nilai arus tabung sinar-X dan waktu eksposi (mAs) yang diberikan maka energi radiasi untuk mencapai objek adalah sama [5]. Hubungan antara arus tabung sinar-X dan waktu eksposi (mAs) terhadap densitas, apabila terjadi peningkatan terhadap nilai arus tabung menjadi dua kali mA semula, maka dilakukan penurunan waktu eksposi menjadi setengahnya untuk menghasilkan nilai densitas yang sama [10].

\subsection{Contrast to Noise Ratio (CNR)}

Penilaian kualitas citra dapat dilakukan secara objektif, salah satunya dengan menggunakan besaran Contrast to Noise Ratio (CNR). Parameter CNR menggambarkan seberapa jauh sinyal dapat dibedakan dengan latar dimana semakin besar nilai kontras maka sinyal akan semakin mudah dibedakan dengan latar. Kontras merupakan perbedaan gelap terang antara bagian-bagian yang membentuk gambar radiografi. Semakin kecil nilai densitas maka semakin besar nilai kontras yang dihasilkan dimana kontras berhubungan dengan nilai CNR, jika semakin tinggi nilai CNRnya maka semakin mudah membedakan sinyal dengan latar. Hubungan antara CNR dan kualitas citra radiograf adalah image yang menunjukkan nilai CNR yang tinggi akan mudah untuk di diagnosis, sedangkan gambar yang memiliki tingkat CNR rendah akan sulit untuk di diagnosis [11]. Adapun persamaan CNR seperti pada Persamaan (1).

$$
C N R=\frac{I_{s}-I_{b}}{\sigma_{b}}
$$

Dimana $\mathrm{I}_{\mathrm{s}}$ adalah nilai rata-rata intensitas sinyal yang diterima oleh IP (imaging plate), $\mathrm{I}_{\mathrm{b}}$ adalah nilai rata-rata intensitas latar (background) dan $\sigma_{\mathrm{b}}$ adalah nilai simpangan baku dari daerah noise [2].

\subsection{Computed Radiography (CR)}

Computed radiography (CR) adalah suatu alat yang dapat menerapkan proses digitalisasi gambar dengan menggunakan lembar atau Photo stimulable Phosphor (PsP) atau $\mathrm{BaFBr} ; \mathrm{Eu}^{2+}$ untuk akuisisi data gambar. Imaging plate (IP) pada CR dapat menyimpan gambar laten yang kemudian akan diproses menggunakan laser serta dapat diterapkan pada kaset analog yang berbasis screen dan film. Sistem kerja CR yaitu pada IP yang telah dieksposi kemudian dimasukkan dalam imaging plate reader. Di dalam imaging plate reader, kaset secara otomatis akan terbuka dan IP dikeluarkan dari kaset. IP yang telah dikeluarkan dari kaset akan dibaca, dihapus dan dikembalikan ke dalam kaset agar dapat digunakan untuk pemeriksaan selanjutnya. Citra yang telah dibaca kemudian ditransfer ke dalam komputer untuk diproses dan ditampilkan pada monitor atau film [1].

\section{Metode Penelitian}

Penelitian mengenai pengaruh kombinasi arus tabung sinar-X dan waktu eksposi terhadap kualitas citra sinar-X dengan menggunakan Computed Radiography dilakukan di Akademi Teknik Radiodiagnostik 
dan Radioterapi (ATRO) Bali. Alat-alat yang digunakan pada penelitian ini yaitu pesawat sinar-X, tabung sinar-X, Computed radiography (CR), meja pemeriksaan, kaset Computed radiography (CR), control panel, step wedge 21 step, dan software program RadiAnt DICOM VIEWER 2020.1 (64 bit). Alat-alat tersebut ditunjukkan pada Gambar 1.

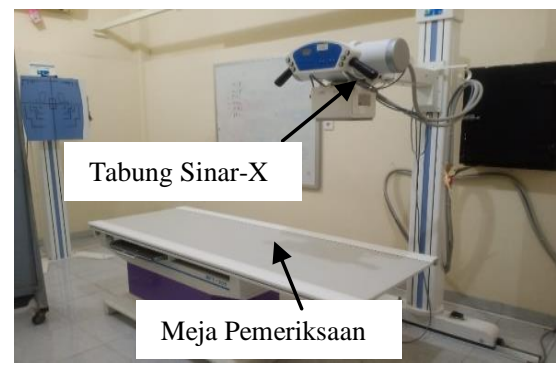

(a)

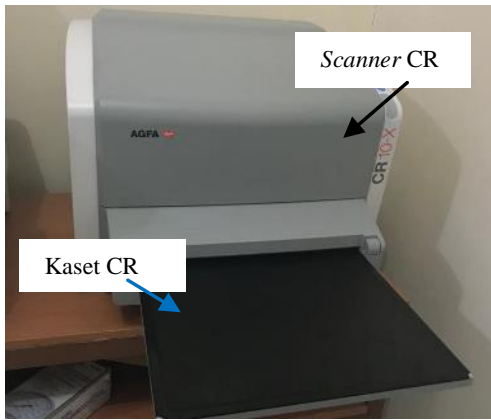

(c)

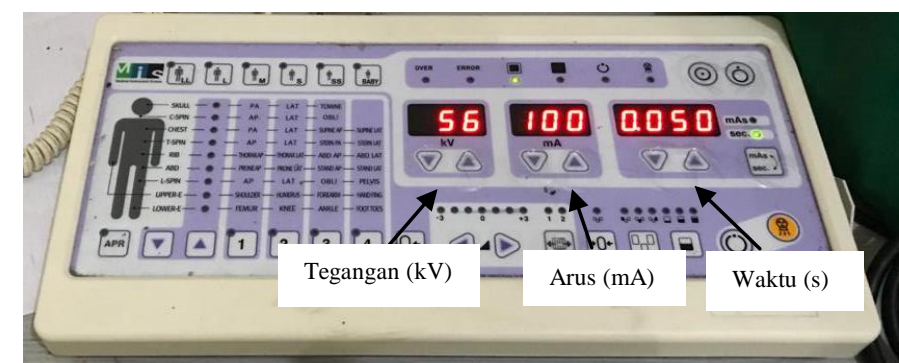

(b)

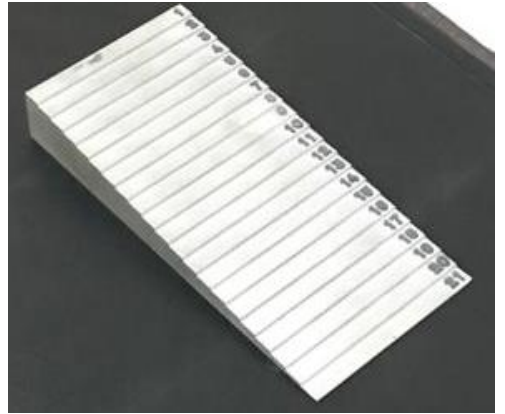

(d)

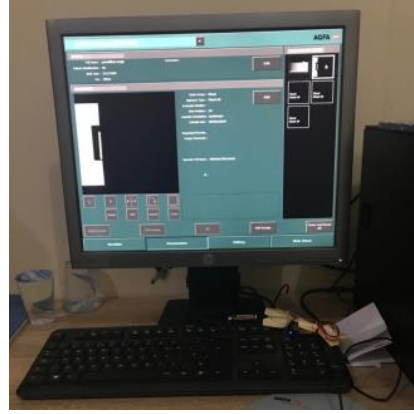

(e)

Gambar 1. (a) pesawat sinar-X, (b) control panel (c) scanner CR dan kaset CR, (d) step wedge, (e) Computed Radiography

Langkah pertama, dilakukan persiapan alat terlebih dahulu kemudian pesawat sinar-X dihidupkan dan dilakukan prosedur warm up dengan kolimator menghadap ke meja pemeriksaan sebelum pesawat sinar-X digunakan. Kaset CR diletakkan di atas meja pemeriksaan. Step wedge diposisikan di tengah kaset CR, dimana bagian paling tebal diletakkan pada arah katoda dan bagian paling tipis diletakkan pada arah anoda. Kemudian kolimator diatur dengan FFD sebesar $100 \mathrm{~cm}$. Lampu kolimator dihidupkan disesuaikan dengan luas step wedge dan central $X$-ray atau arah sinar tegak lurus dipertengahan step wedge. Selanjutnya faktor eksposi diatur dengan tegangan tabung sinar-X dibuat konstan sebesar $56 \mathrm{kV}$, arus sebesar $100 \mathrm{~mA}$ dan waktu eksposi 0,050 s. Kemudian dilakukan eksposi. Selanjutnya pada kaset CR yang telah di eksposi dilakukan proses image reader untuk menampilkan hasil citra pada layar monitor CR. Proses penghapusan kaset CR pada bagian lain dari image reader sehingga IP dapat digunakan kembali. Langkah diatas dilakukan kembali dengan variasi arus tabung sinar-X dan waktu eksposi sebagai berikut, variasi 2 sebesar $125 \mathrm{~mA}$ dengan $0,040 \mathrm{~s}$, variasi 3 sebesar $160 \mathrm{~mA}$ dengan $0,032 \mathrm{~s}$, variasi 4 sebesar $200 \mathrm{~mA}$ dengan $0,025 \mathrm{~s}$, dan variasi 5 sebesar $250 \mathrm{~mA}$ dengan $0,020 \mathrm{~s}$. Setelah selesai dilakukan pengambilan data, kemudian dilakukan pembacaan hasil citra nilai $\mathrm{I}_{\mathrm{s}}, \mathrm{I}_{\mathrm{b}}$, dan $\sigma_{\mathrm{b}}$ menggunakan software program RadiAnt DICOM VIEWER 2020.1 (64 bit) sesuai dengan ROI (Region of Interest) yang telah ditentukan pada masing-masing ketebalan step wedge. Pembacaan nilai pada ROI dilakukan dengan 5 pemilihan titik baca dengan jarak $0,2501 \mathrm{~cm}$ antara ROI, ditunjukkan pada Gambar 2. Dari nilai $\mathrm{I}_{\mathrm{s}}, \mathrm{I}_{\mathrm{b}}$, dan $\sigma_{\mathrm{b}}$ kemudian dilakukan perhitungan untuk mentukan nilai CNR.

Adapun analisis data menggunakan IBM SPSS Statistics 26, langkah pertama yang dilakukan yaitu uji normalitas data, dilanjutkan dengan uji homogenitas dan uji One-Way ANOVA saat memenuhi syarat data berdistrubusi normal dan varian antar variasi bersifat homogen. Selanjutnya untuk menentukan nilai optimal CNR dari kombinasi arus tabung sinar-X dan waktu eksposi dilakukan berdasarkan grafik antara variasi arus tabung sinar-X dan waktu eksposi terhadap nilai CNR. 


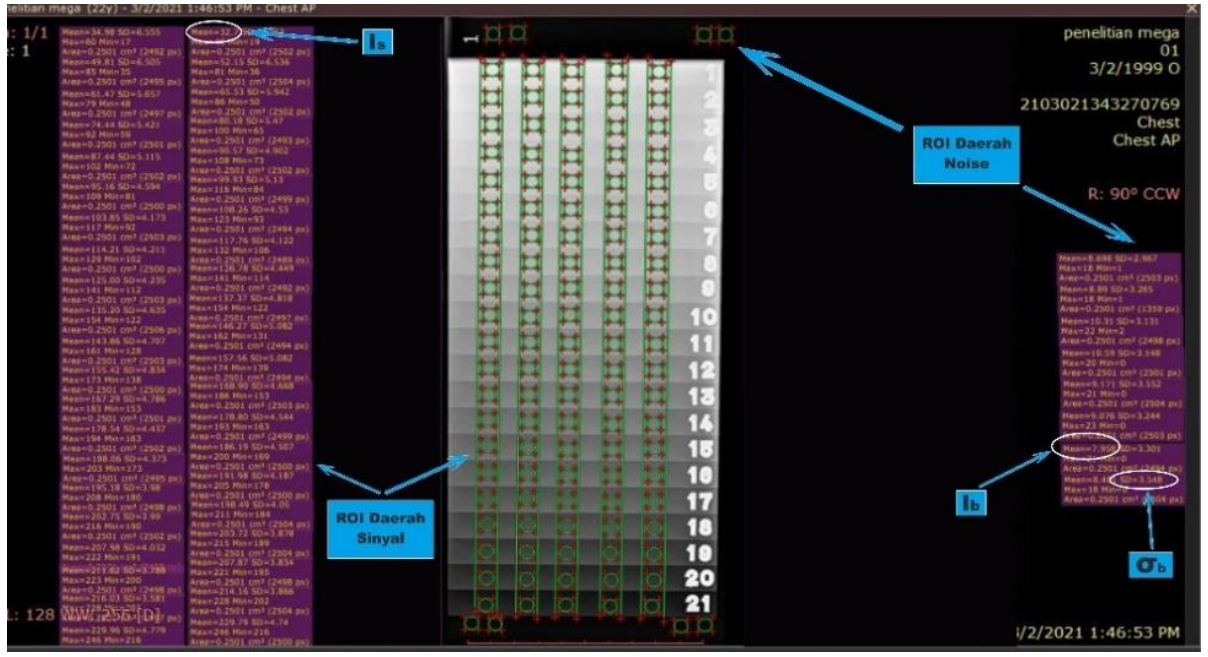

Gambar 2. Proses pembacaan nilai $\mathrm{I}_{\mathrm{s}}, \mathrm{I}_{\mathrm{b}}$ dan $\sigma_{\mathrm{b}}$.

\section{Hasil Dan Pembahasan}

Hasil perhitungan nilai CNR pada kelima variasi kombinasi dapat dilihat pada Tabel 1.

Tabel 1. Tabel nilai CNR.

\begin{tabular}{ccccccc}
\hline & Ketebalan & \multicolumn{5}{c}{ NILAI CNR } \\
\cline { 5 - 7 } No. & $\begin{array}{c}\text { Step wedge } \\
(\mathrm{mm})\end{array}$ & Variasi 1 & Variasi 2 & Variasi 3 & Variasi 4 & Variasi 5 \\
\hline 1. & 31,5 & 67,04 & 66,46 & 69,12 & 70,49 & 69,83 \\
2. & 30,0 & 62,19 & 62,39 & 62,38 & 63,90 & 63,41 \\
3. & 28,5 & 60,46 & 60,89 & 60,28 & 62,97 & 61,72 \\
4. & 27,0 & 59,18 & 59,36 & 59,19 & 61,90 & 60,45 \\
5. & 25,5 & 57,60 & 57,79 & 57,71 & 60,06 & 58,95 \\
6. & 24,0 & 55,76 & 56,24 & 56,21 & 56,77 & 57,03 \\
7. & 22,5 & 54,10 & 54,71 & 52,80 & 55,03 & 55,13 \\
8. & 21,0 & 51,98 & 52,22 & 52,47 & 52,82 & 53,03 \\
9. & 19,5 & 48,93 & 49,22 & 50,20 & 49,60 & 50,51 \\
10. & 18,0 & 45,58 & 46,62 & 47,20 & 47,02 & 47,46 \\
11. & 16,5 & 42,54 & 43,58 & 44,31 & 43,98 & 44,10 \\
12. & 15,0 & 40,10 & 40,48 & 41,32 & 39,79 & 40,91 \\
13. & 13,5 & 36,93 & 37,11 & 38,88 & 38,26 & 36,53 \\
14. & 12,0 & 34,11 & 33,41 & 35,67 & 35,64 & 34,82 \\
15. & 10,5 & 31,28 & 31,48 & 32,77 & 31,24 & 31,76 \\
16. & 9,0 & 28,76 & 29,38 & 30,52 & 28,92 & 29,15 \\
17. & 7,5 & 26,01 & 26,13 & 27,78 & 26,09 & 25,90 \\
18. & 6,0 & 22,17 & 22,46 & 24,74 & 22,71 & 23,17 \\
19. & 4,5 & 17,26 & 18,32 & 20,51 & 17,16 & 18,40 \\
20. & 2,0 & 12,91 & 14,28 & 15,96 & 13,25 & 13,79 \\
21. & 1,5 & 6,99 & 8,36 & 9,74 & 7,10 & 7,63 \\
\hline
\end{tabular}

Berdasarkan hasil perhitungan nilai CNR tersebut, analisis pengaruh kombinasi arus tabung sinar-X dan waktu eksposi ditentukan menggunakan uji One-Way ANOVA, serta hasil analisis dapat dilihat pada Tabel 2. Dasar pengambilan keputusan dalam uji One-Way ANOVA adalah jika nilai p-value $>0,050$ maka Ho diterima dan Ha ditolak, jika nilai p-value < 0,050 maka Ho ditolak dan Ha diterima. Hipotesis penelitian yaitu Ho: Tidak ada pengaruh variasi kombinasi arus tabung sinar- $\mathrm{X}$ dan waktu eksposi 
terhadap nilai CNR. Ha: Ada pengaruh variasi kombinasi arus tabung sinar-X dan waktu eksposi terhadap nilai CNR.

Tabel 2. Uji One-Way ANOVA pada nilai CNR.

\begin{tabular}{ccc}
\hline & Uji One-Way ANOVA \\
\hline Kategori & p-value & Keterangan \\
Between Groups & 0,999 & Ho diterima, Ha ditolak \\
\hline
\end{tabular}

Berdasarkan Tabel 2 di atas dapat diketahui nilai p-value sebesar 0,999>0,050 sehingga Ho diterima dan Ha ditolak maka dapat disimpulkan bahwa tidak ada pengaruh variasi kombinasi arus tabung sinar-X dan waktu eksposi terhadap nilai CNR. Selanjutnya untuk menentukan nilai optimal dari CNR dari kombinasi arus tabung sinar-X dan waktu eksposi dilakukan berdasarkan grafik antara variasi arus tabung sinar-X dan waktu eksposi terhadap nilai CNR. Grafik dapat dilihat pada Gambar 3.

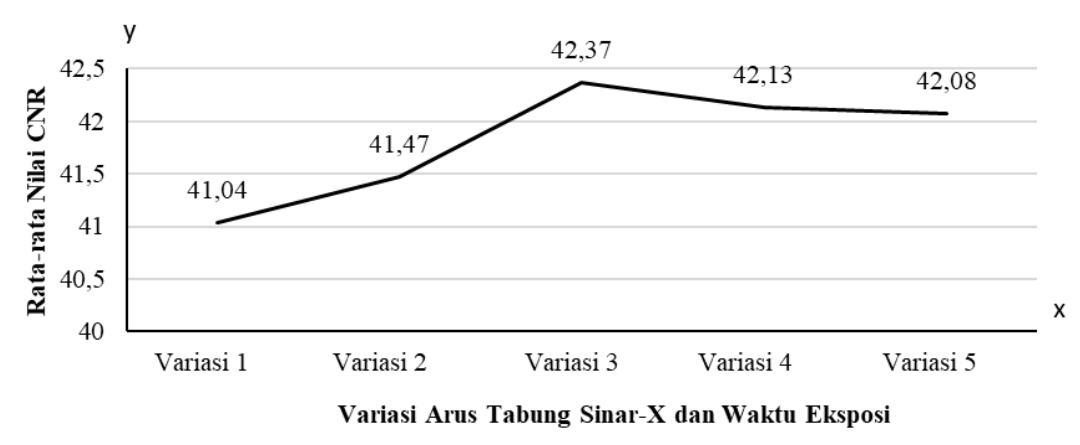

Gambar 3. Grafik variasi kombinasi arus tabung sinar-X dan waktu eksposi terhadap nilai CNR.

Pada Gambar 3 dapat diamati bahwa nilai CNR pada variasi 1 sebesar 41,04 sedangkan pada variasi 2 nilai CNR sebesar 41,47 dan mengalami kenaikan dari variasi 1 ke variasi 2 sebesar 0,43. Pada variasi 2 mengalami kenaikan kembali sebesar 0,90 ke variasi 3 dengan nilai CNR pada variasi 3 sebesar 42,37. Kemudian mengalami penurunan nilai pada variasi 4 sebesar 0,24 dengan nilai CNR pada variasi 4 sebesar 42,13 serta mengalami penurunan kembali pada variasi 5 sebesar 0,05 dengan nilai CNR sebesar 42,08. Nilai optimal pada nilai CNR dari kombinasi arus tabung sinar-X dan waktu eksposi pada variasi 3 dengan besar arus tabung sinar-X sebesar $160 \mathrm{~mA}$ dan waktu eksposi sebesar 0,032 s. Hal tersebut menunjukan bahwa dengan diberikan arus tabung sinar-X sebesar $160 \mathrm{~mA}$ secara kuantitas elekron dapat dikatakan cukup saat dikombinasikan dengan lamanya waktu eksposi sebesar 0,032 s untuk menghasilkan gambar dengan kualitas citra yang paling optimal yaitu mampu menunjukan perbedaan derajat gelap terang yang jelas antar organ yang memiliki kerapatan berbeda.

Pada penelitian ini menghasilkan nilai CNR pada kelima variasi kombinasi arus tabung sinar-X dan waktu eksposi menunjukan tidak ada perbedaan rentang nilai yang signifikan dari masing-masing variasi dapat dilihat pada Gambar 4.

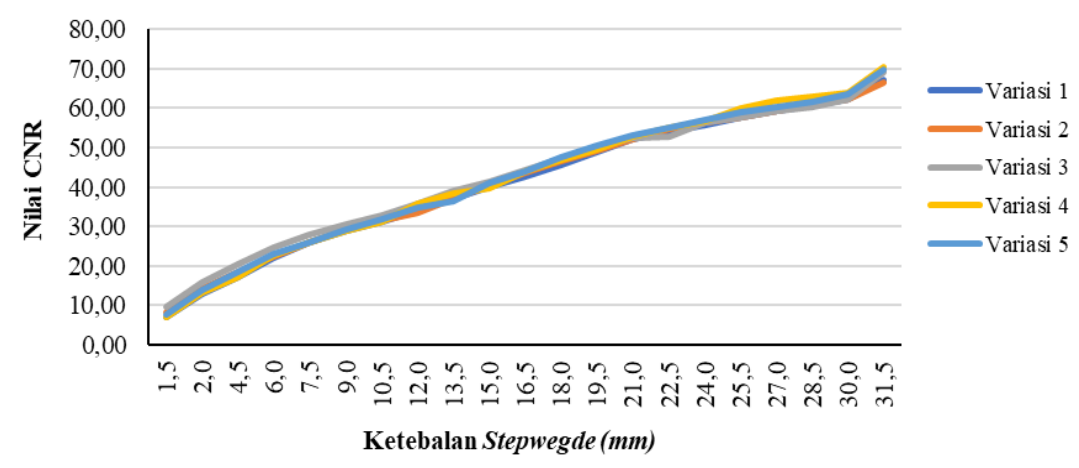

Gambar 4. Grafik hubungan antara variasi ketebalan step wedge terhadap nilai CNR pada setiap variasi mAs. 
Pada Gambar 4 menunjukan secara umum bahwa semakin besar ketebalan step wedge nilai CNR akan semakin besar. Dari nilai CNR mimimum dan maksimum pada kelima variasi dapat disimpulkan bahwa rentang nilai CNR pada kelima variasi tidak terlalu jauh sehingga menghasilkan grafik dari variasi 1 sampai variasi 5 saling berdekatan maka dapat dikatakan bahwa dari kelima variasi tersebut tidak menyebabkan pengaruh yang terlalu besar pada nilai CNR.

Kualitas citra dapat ditentukan dengan nilai CNR, dimana semakin kecil nilai densitas maka semakin besar nilai $I_{s}$ dan diikuti dengan semakin besar nilai kontras yang dihasilkan. Kontras merupakan perbedaan derajat kehitaman antara bagian- bagian yang membentuk gambar. Kontras citra berhubungan dengan nilai CNR, jika nilai CNR semakin tinggi maka semakin mudah membedakan sinyal dengan latar [12]. Kontras citra merupakan kemampuan untuk membedakan 2 objek yang saling berdekatan yang memiliki densitas yang berbeda. Kontras citra masih berhubungan dengan densitas citra [13].

Besarnya nilai densitas dipengaruhi oleh besarnya nilai arus tabung sinar-X dan waktu eksposi. Dimana setiap kenaikan nilai arus tabung sinar-X akan menyebabkan penurunan nilai waktu eksposi untuk menghasilkan nilai output yang konstan sehingga intensitas dari output radiasi yang terdistribusi menuju film akan memiliki nilai yang sama atau tidak ada perbedaan rentang densitas yang signifikan. Hubungan antara arus tabung sinar-X dan waktu eksposi (mAs) terhadap densitas, apabila terjadi peningkatan terhadap nilai arus tabung menjadi dua kali arus tabung (mA) semula, maka dilakukan penurunan waktu eksposi (s) menjadi setengahnya untuk menghasilkan nilai densitas yang sama [10]. Hubungan densitas dengan kontras yaitu saat energi radiasi sinar-X akan meningkat, akan menyebabkan densitas pada film meningkat dan mengurangi kontras dari objek [5].

Hasil dari penelitian di batasan masalah dengan mengkombinasikan nilai arus tabung sinar-X dan waktu eksposi menjadi 5 variasi, jika hasil nilai arus tabung sinar-X dan waktu eksposi (mAs) pada kelima variasi konstan akan menghasilkan tidak ada perbedaan rentang nilai densitas yang signifikan dan diikuti dengan tidak ada perbedaan rentang nilai kontras pada masing-masing variasi, sehingga hasil dari nilai densitas dan kontras tersebutlah yang menyebabkan nilai CNR pada kelima variasi saling berdekatan atau dapat dikatakan bahwa tidak ada pengaruh kombinasi arus tabung sinar-X dan waktu eksposi yang terjadi terhadap nilai CNR.

\section{Kesimpulan}

Setelah dilakukan pengambilan data dan analisa data dapat diketahui bahwa hanya dengan mengkombinasikan nilai arus tabung sinar-X dan waktu eksposi, jika hasilnya konstan sesuai dengan arus tabung sinar-X dan waktu (mAs) yang diberikan tidak akan mempengaruhi nilai CNR secara signifikan. Nilai optimal CNR sebesar 42,37 variasi 3 dengan besar arus tabung sinar-X sebesar $160 \mathrm{~mA}$ dan waktu eksposi sebesar 0,032 s.

\section{Ucapan Terima Kasih}

Penulis menyampaikan terimakasih kepada seluruh staff di Akademi Teknik Radiodioagnostik dan Radioterapi (ATRO) Bali yang telah memberikan izin dan bantuan berupa fasilitas dalam penelitian ini, serta staf dosen Program Studi Fisika, FMIPA, UNUD yang telah memberikan saran serta masukan terkait penelitian ini.

\section{Pustaka}

[1] A. M. Yusnida, Suryono, Uji Image Uniformity Perangkat Computer Radiography dengan Metode Pengolahan Citra Digital, Youngster Physics Journal, vol. 3, no. 4, 2014, pp. 251-256.

[2] C. A. Louk, dan G. B. Suparta, Pengukuran Kualitas Sistem Pencitraan Radiografi Digital Sinar-X, Berkala MIPA, vol. 24, no. 2, 2014, pp. 149-166.

[3] Alfiati, Studi Efek Heel pada Film Radiografi, Skripsi, Jurusan Fisika, Fakultas Matematika dan Ilmu Pengetahuan Alam Universitas Hasanuddin, 2013.

[4] N. N. Ratini, I. M. Yuliara, Windaryoto, Anode Heel Effect Application with Step Wedge Against Effect of Signal to Noise Ratio in Computed Radiography, International Journal of Health Sciences, vol. 4, no. 3, 2020, pp. 75-82.

[5] M. D. Ginting, Analisis Kualitas Gambar Radiografi pada Pemeriksaan Mammae Terhadap Densitas Gambar dan Faktor Eksposi, Skripsi, Departemen Fisika, Fakultas Matematika dan Ilmu Pengetahuan Alam Universitas Sumatera Utara, 2016. 
[6] A. Musfira, Analisis Perbandingan Dosis Serap Radiasi Foto Thorax pada Pasien dengan Berbagai Tingkat Umur, Skripsi, Jurusan Fisika, Fakultas Sains dan Teknologi Universitas Islam Negeri Alauddin, 2016.

[7] A. Pasinringi, Pengujian Kesesuaian Antara Lapangan Penyinaran Kolimator dengan Berkas Radiasi yang dihasilkan pada Pesawat Sinar-X Mobile di Rumah Sakit Umum Daerah Tani dan Nelayan Gorontalo, Skripsi, Jurusan Fisika, Fakultas Matematika dan Ilmu Pengetahuan Alam Universitas Hasanuddin, 2012.

[8] Wilks J. Robin, Principles of Radiological Physics, 3th Edition, Melbourne and New York Churcill Livingston, 2000.

[9] T. L. Fauber, Radiographic Imaging and Exposure Fourth Edition, Associate Professor and Radiography Program Director, Department of Radiation Sciences, School of Allied Health Professions, Virginia Commonwealth University, Richmond, Virginia, 2012.

[10] Q. B. Carrol, Radiographic Exposure Processing and Quality Control. USA: Charles C. Thomas, 2000.

[11] N. P. E. Wibowo, Susilo, Sunarno, Uji Profisiensi Citra Hasil Eksposi Sistem Radiografi Digital di Laboratorium Fisika Medik Unnes, Unnes Physics Journal, vol. 1, no. 2, 2016, pp. 527-539.

[12] A. A. A Diartama, K. S. Devi, R. H. A. Siagian, Triningsi, Pengaruh Penggunaan Aturan 10 kVp Rule dengan Computed Radiography Terhadap Signal to Noise Ratio (SNR) dan Contras to Noise Ratio (CNR) pada Thorax PA, IMEJING, vol. 2, no. 2, 2018, pp. 56-63.

[13] A. P. Utami, D. A. Mulyani, A. N. Istiqomah, Pengaruh Variasi Arus Tabung Terhadap Kualitas Citra dan Dosis Radiasi pada Pesawat Sinar-X High Generator, Tesis, Universitas A'isyiyah Yogyakarta, 2019. 